\title{
Reflections on "doing" cultural geography - "being" a cultural geographer in the Netherlands
}

\author{
B. van Hoven \\ Department of Cultural Geography, University of Groningen, \\ P.O. Box 800, 9700 AV Groningen, The Netherlands \\ Received: 21 July 2010 - Published in Soc. Geogr. Discuss.: 12 August 2010
Revised: 20 January 2011 - Accepted: 22 February 2011 - Published: 22 March 2011
}

\begin{abstract}
In this article, I explore Dutch social geography in the context of "the cultural turn". In so doing, I extensively draw on writing from the Anglo-American context which somewhat complicates the matter. Barnett (1998) implied that the "cultural turn" is not a "coherent and singular process" (379) which will emerge from my reflections as well. But even though the disciplines have undergone different ways of becoming, Dutch geographies are, formally, valued and assessed by procedures that have developed alongside, if not as a part of, the cultural turn(s) in the United Kingdom. In the Netherlands, different Departments have been a part of (or apart from) the cultural turn in different ways. In this article, I draw on some of the similarities and differences but will focus to a large extent on my own institutional context at the University of Groningen.
\end{abstract}

\section{Prelude}

My "being" a cultural geographer necessitated a journey through different disciplines and countries. As a teenager, I discovered a passion for the environment. I volunteered for various environmental organizations, for example observing the occurrence and behavior of crane birds for the World Wildlife Funds, and later "specialised" in forest issues and environmental education as a member of a local Greenpeace group in Germany. As a result, I first began studying biology and later "added" geography out of necessity when I switched to a study that would lead to a qualification as Gymnasium teacher in both of these subjects. During a student exchange year in the UK, I took both biology and geography courses but ended up with a Bachelor in (Physical) Geography because, in the British system, I had earned more credits in that subject. When a $\mathrm{PhD}$ opportunity presented itself in Social Geography, I re-oriented myself in order to conduct a study on the changing geographies of women in rural Eastern Germany. This was a lucky turn in my training as a geographer since it enabled me to apply for a position in the regional geography department at the University of Groningen (Netherlands) in 1999. Through my work on gender, I first mingled with those working on gender issues - at least at

Correspondence to: B. van Hoven (b.van.hoven@ rug.nl) international conferences. In Groningen feminist geography was not represented in teaching or research and gender was not considered a particularly relevant subject in the context of the faculty's research programmes at the time ${ }^{1}$. Therefore, I began to look more broadly at issues of difference, inclusion and exclusion and, in so doing, began to think more and more explicitly about what kind of a geographer I am, where my "conceptual home" is and even, during frequent debates with colleagues, what "geography" is, particularly cultural geography.

\footnotetext{
${ }^{1}$ It must be noted, however, that Dutch geography had been one of the forerunners as Linda Peake has demonstrated in an overview of feminist geography teaching in 1989. The University of Amsterdam introduced an elective course "Geographical Women's Studies" as early as 1983 (and until 2000) (see van Hoven et al., 2010) and Utrecht taught a successful course on feminist geography in 1999 still, attracting 241 students. Droogleever Fortuijn (2004) touches on why a more explicit focus on gender and feminist geography has diminished in her article on gender representation in geography the Netherlands. She noted, for example, that at that time only $19 \%$ of all human geography faculty were women. She regarded this as a problem because of the different ways of practicing geography and the different subjects female geographers engage with compared with their male colleagues. It can be added that most women are in the lower echelons of the academic hierarchy (Droogleever Fortuijn, 2004). A few Dutch geographers are engaged in feminist geography, however, the total number of feminist geographers is very low, some of them work part-time and all are engaged in other issues as well.
} 


\section{A (non-representative) review of cultural geogra- phy in the Netherlands}

Gill Valentine (2001) ascribes the cultural turn to the United Kingdom, the United States and perhaps Australia, and Barnett's (1998) earlier discussion of the cultural turn as fashion or progress equally implies that it is largely a turn that took place in the UK. Did such writing simply ignore the cultural turns elsewhere or was the cultural turn indeed geographically limited to the countries named? Based on a (non-representative) review of Dutch social geography in the Netherlands, I argue that in spite of publications such as Dutch windows. Cultural geographical essays on The Netherlands (published in 2003 by Gorp et al., geographers from Utrecht), initiatives emerging from the Humboldt lecture series in Nijmegen, and a number of publications by individuals at the University of Amsterdam, Nijmegen and Groningen that could be "labelled" cultural geography, one might not speak of a broadly recognised "cultural turn" in Dutch geography. Barnett (1998) illustrates the mechanisms which aided the cultural turn in the UK. In the following, I briefly want to outline some developments in social geography in the Netherlands and, using Barnett's discussion, illustrate that such mechanisms were lacking in the Netherlands (at least in the 1990s).

The advent of Dutch geography is related to Dutch colonialism (until the independence of the Dutch Indies in 1949). In addition, developments in the discipline can be associated with the demand for geography teachers in schools (van der Vaart et al., 2004). Pieter Roelof Bos, a geography teacher from Groningen, successfully promoted a geography akin to the natural sciences (in the late 19th century), in which the "detailed study of the natural forms in the world should be at the basis of comparison, classification, and generalization. In geography, 'the social' should follow 'the physical' " (van der Vaart et al., 2004:140, see also Knippenberg and van Schendelen, 2002). Since the 1930s, the role of geography and geographers remained prominent as they played an important part in large-scale planning projects in the struggle against water and development of new land. Van der Vaart et al. (2004) assert that "Dutch geographers may be seen as the "socio-spatial engineers of the welfare state" " (141). Since this article is concerned with the institutional context in which local and personal ways of doing geography evolve, it is important to note that ways of doing geography were roughly differentiated based on geographic regions. Roughly, a differentiation could be made based on the "old land" (Utrecht geographers and their focus largely on socio-economic problems in cities and regions) and the "new", or reclaimed land (Amsterdam geographers and their focus on the "struggle against water" and developments on the new land) (see de Pater, 2001) ${ }^{2}{ }^{3}$. Musterd and De Pa-

\footnotetext{
${ }^{2}$ The geographic institutes at Groningen, Nijmegen, the Free University (and I would add Wageningen) were established after the war.
}

ter (2003) concluded, in their overview of developments in human geography in the Netherlands, that geography's roots in spatial planning and regional-economic policy rather than an interest in socio-cultural processes still persist, and they represent the discipline as an applied and practical science. Droogleever Fortuijn (2004) added to this perception by noting that many Dutch geography graduates find employment in the civil service or as policy consultant, Dutch geographers are often involved directly in policy making through their role as advisory board members and media experts and much research is government funded ${ }^{4}$. For those working in a geography department in the Netherlands, this means that the choice of topics and (lack of) funded research opportunities reflect these constraints. Returning to the virtual disappearance of gender from the curriculum, this can be explained then by a lack of urgency from a societal perspective. The "gender issue" had after all, at least according to policy makers, been solved (see van Hoven, 2009). Geography in the Netherlands then has, in general, been less "abstract" but more "applied" than geography in the UK. If we take Barnett's depiction of the cultural turn, not many Dutch social geographers' way of "doing" cultural geography may qualify. Barnett conceives of the cultural turn as: "a commitment to epistemologies, often loosely labelled 'poststructural', that emphasise the contingency of knowledge claims and recognise the close relationship among language, power, and knowledge" (1998:380).

In addition, if we consider the mechanisms relevant to establishing what the cultural turn implied and what the "new cultural geography" came to be, much of it is located in the UK and utilizes the English language ${ }^{5}$. Barnett lists the

\footnotetext{
${ }^{3}$ With thanks to Ben de Pater for pointing this out.

${ }^{4}$ Some research is funded by national research organisations (Netherlands Organisation for Scientific Research, NWO, and the Royal Dutch Academy of Sciences KNAW) but here, too, the themes reflect areas of high policy priority or strategic international partnerships. There are few opportunities for senior researchers in geography, most calls are targeted at $\mathrm{PhD}$ research.

${ }^{5}$ See also more recent reflections on language and hegemony in geography: Short et al., 2001; Garcia-Ramon, 2003; Helms et al., 2005; Garcia-Ramon et al., 2006. Garcia-Ramon et al. (2006) discuss the dominance of the English language in Gender, Place and Culture and explain: "we take a short look at publications in GPC from a quantitative perspective. Out of a total of 242 authors of articles and viewpoints, only 19 are not based in Angloamerican universities or research centres, that is $7.3 \%$ of the total [...]. US and UK authors represent around $64 \%$ of the total (both countries are quite evenly represented) [...] The share of non-Angloamerican authors does not increase through the 12 years of publication [... ] Looking at the bibliography in the articles, we observe that Angloamerican authors are not using sources written in languages other than English and references are massively monolingual (in English). English sources reach over 95" (2). (see also Short et al., 2001, for a more extensive analysis of journals). I would also recommend a Dutch contribution to this discussion, i.e. Bosman and de Pater (2007).
} 
special issues, new journals, conferences and institutional developments emerging in the late 1980s and early 1990s that helped authorize "programmatic and theoretical statements on the 'new' cultural geography" $(1998,381)$. Commercial academic publishing played an important part, too, with new introductory readers (featuring mostly UK or US authors) that outlined and defined themes, methods and directions in cultural geography. In the Netherlands, no new journals or conferences around the new cultural geography emerged. In addition, (the website of) the national research institute NETHUR, which encompasses the geography departments in the Netherlands, does not imply a particular interest in outcomes of the cultural turn either ${ }^{6}$. In fact, a brief scan through the publication lists of geography departments in Amsterdam, Utrecht, Groningen and Nijmegen verifies a lack of concern for "being known" (in international circles) for one's work in cultural geography: many articles have appeared in urban planning, housing journals, journals on (geo)politics, or journals outside of geography, and there is a notable bulk of work that appears in Tijdschrift voor Economische en Sociale Geografie (TESG) and GeoJournal. A considerable number of articles appear in policy-oriented, Dutch journals and magazines and many geographers also write for the Dutch magazine Geografie- none of these are esteemed highly in research assessment exercises such as the most recent one in 2007 (which was influenced strongly by UK developments in publishing and ratings thereof). Adapting West and Fenstermaker's (1995) statement that gender "is accomplished in interaction with others" (21, emphasis added $)^{7}$, it can be argued then that available networks within the Netherlands have not provided much interaction that would allow one to identify (and be identified as) as "cultural geographer" (see also Bosco, $2006^{8}$ ).

An interesting aspect of the rise of new cultural geography is, according to Barnett (1998), the presence of academic celebrities and fandom. Barnett (1998) notes: "Geography has always had its own favoured academic personalities, of course. What is perhaps new about the present conjuncture is how some of them have recently been swept into international circuits of academic celebrity, a move that is depen-

\footnotetext{
${ }^{6}$ The site lists projects headed by full professors rather than all staff. It is important to note, then, that research by younger staff who adopt less conservative approaches are under-represented.

${ }^{7}$ West and Fenstermaker (1995) further maintain: "while individuals are the ones who do, the process of rendering something accountable is both interactional and institutional in character: it is a feature of social relationships, and its idiom derives from the institutional arena in which those relationships come to life" (22)

${ }^{8}$ Fernando Bosco notes: "From the perspective of ANT [Actornetwork theory], I would no longer be a geographer with the ability to write papers and produce knowledge if my computer, my colleagues, my books, my job, my professional network, and everything else in my life that allows me to act as what I am were taken away from me [...] if that were to happen, I would become something different." (2006:137)
}

dent less upon internal disciplinary modes of evaluation than on the shifting imperatives of knowledge dissemination [...] the cultural turn in human geography involves a turn toward a set of disciplines in which distinctive individualised modes of authority are predominant. [...] Fandom as the corollary of the rise of academic celebrity has implications for the ways in which theoretical ideas are discussed, criticised, and evaluated." (388)

It is, perhaps, precisely in this treatment of celebrity geographers that a resistance to UK's cultural turn in the Netherlands can be explained. The Dutch national spirit has been characterized as average and sober which is exemplified by the Dutch saying "Doe maar gewoon, dan doe je al gek genoeg" ("Just act normally, then you act crazily enough") (see Sanders, commentary in the newspaper NRC, 2008). It seems that, certainly prior to the increasing pressure to "publish [in English peer-reviewed journals] or perish", "just doing" geography may have been sufficient ${ }^{9}$. And not to forget: geographers did have a rather important societal role (as I noted previously) which might have nurtured their "being" geographer sufficiently. Whilst this may support the notion that cultural geography has been viewed largely as a "fashion" in the Netherlands, it underplays the importance of past and ongoing initiatives that have surfaced here. I already mentioned some initiatives from Utrecht and Nijmegen above, and must add a recent "mini-symposium" entitled Van folklore tot kapitaal: de "cultural turn" in de Nederlandse geografie ("From folklore to capital: the cultural turn in Dutch geography") organized as part of the farewell for Amsterdam political geographer Hans Knippenberg (well-known for his work on religion) in June 2008. If social geography in the Netherlands has, in general, been less accepting of the cultural turn, what then does a Dutch cultural geography look like? In the following, I illustrate a Dutch cultural geography by using my own department of Cultural Geography in Groningen as an example. This is, incidentally, the only Department in the Netherlands carrying "Cultural" in its name.

\section{Perspectives from Groningen}

In 2004, the Department of Regional Geography at the University of Groningen reinvented itself as Department of Cultural Geography. A key reason was, as Valentine (2001) similarly states for UK's cultural turn, a desire for a transformation into a "cool and sexy subject" (167) which might draw different and more students. However, this reinvention

\footnotetext{
${ }^{9}$ In this context, a comment by Jan van Weesep is worth noting: In 2006, van Weesep discussed research assessments in the Netherlands. In so doing, he briefly provided a background of how Dutch geographical research had been organized, claiming that until the early 1980s, research was fragmented. He continues: "there was overlap between work at the different universities, and developments in the discipline abroad rarely inspired Dutch geographers.' (752, emphasis added)
} 
has also brought forth a re-assessment of the curriculum and opened up new spaces for research. Cultural geography was introduced in the bachelor as part of more general courses (e.g. through a guest lecture on gender, and later otherness (and orientalism), using, for example, Crang, 1998) as well as a full course on cultural geography (structured around Holloway and Hubbard (2000) and later adding Cresswell (2004)). With the introduction of the Master Cultural Geography, students played an important role in shaping cultural geography. For example, after a first assessment of a potential handbook by members of staff (e.g. through a discussion-afternoon about the book), students commented on accessibility and relevance in their "Dutch context" (and that of their perceived future employment). As a result, the course tried out and abandoned several books over the years (e.g. Shurmer-Smith, 2002; Blunt et al., 2004), eventually arriving at Oakes and Price (2008). Master theses were encouraged around the themes of the books but depending on the supervisor, the subjects were dealt with in a more conservative way, or a more "post-structural way". In so doing, UK cultural geography, as represented in the handbooks used, was often modified to the particular Dutch context ${ }^{10}$.

The link between research and teaching is strong in Groningen (as was indicated as characteristic for the Netherlands using Droogleever-Fortuijn's reflections). Many members of staff in cultural geography experience their work as embedded in teaching and feel they work primarily in an educational institute (rather than a research institute ${ }^{11}$ ). The combination of teaching and research is reflected in themes adopted in the curriculum but also in co-authored (often Dutch) articles based on student research ${ }^{12}$. This all may appear as a restriction, especially if staff were to aspire international academic superstardom ${ }^{13}$, but it certainly opens up opportunities as well. For example, there has been a considerable emphasis on the "doing" which includes (time-consuming) data collection, or experimenting with new methods such as the use of video (which is a part of the course "Representing Places" in which Master students experiment with journalistic writing, photography and videography in crafting stories about places) ${ }^{14}$.

\footnotetext{
${ }^{10}$ However, the framework of reference remained cultural geography as represented through Anglo-American literature. For example, the quality of a thesis is determined, to a large extent, by its embededdness in international (peer-reviewed) literature.

${ }^{11}$ Even though there is increasing pressure to place more emphasis on internationally appreciated research output, sometimes at the cost of teaching.

${ }^{12}$ See Meijering and van Hoven, 2003; van Hoven and Poelman, 2003; Klunder and Haartsen, 2007; Klaassens et al., 2009; Dickhoff and Groote, 2009; Salemink et al., 2009; van Hoven and Elzinga, 2009; Zijp and Groote, 2009.

${ }^{13}$ And perhaps it does present an excuse to neglect publishing strategies of a more international nature.

${ }^{14}$ However, often the "doing" consumes so much time that there is little left for reflection, theoretical embedding and writing (in aca-
}

In a nutshell then, the Department of Cultural Geography in Groningen has been interested, predominantly, in "Making Places" which implies an interest in relations between people and places and the role of difference in establishing such relations. The way in which cultural geography in Groningen can be defined is akin to what Mitchell, and Cosgrove and Jackson defined as the cultural in "new cultural geography" (in Valentine, 2001:167): "Mitchell (1995) suggests that it is fundamentally about the patterns and markers of differentiation between people, the processes through which these are made, and the ways in which these processes, patterns and markers are represented and ordered. For Cosgrove and Jackson (1987:99) it is 'the medium through which people transform the mundane phenomenon of the material world into a world of significant symbols to which they give meanings and attach values'". (emphasis added)

In order to study interactions between people and places, several different "entry points" are used ${ }^{15}$ : there is research which is interested in the natural and social processes that impact on the formation and representation of places (see Mouissie et al., 2008 and Meijering et al., 2007), some research draws on regression models in order to discover and visualise patterns (Haartsen et al., 2003; Klaassens et al., 2009), while another focuses more on issues of difference, power and identities, and utilises in-depth interviews to study the personal experiences of respondents (such as in research on prison spaces (Sibley and van Hoven, 2009)) . More recently, methods have begun to include photography, video, or walks (Trell and van Hoven, 2010) in order to explore "the unseen" aspects (at least when compared with interviewing) of how people relate to and interact with places.

A key concern for the way in which geography is done (and transmitted to students) is an emphasis on empirical investigation, something which is perhaps less prominent in cultural geography in the UK. Barnett (1998) commented on the lack of empirical investigation in his discussion of the cultural turn but personal experience confirms that this may still be the case, at least in part. An anonymous referee for David Sibley's and my article "Just Duck: The Role of Vision in the Production of Prison Spaces" (2008) commented: "The author(s) do what is so important, and relatively rare these days: go out into the world, conduct some relatively simple empirical research, and find that the big theorists of prison and by extension the disciplinary society we live in, don't know much about prison (indeed, they get some important points exactly wrong), and so we must wonder about their general theories, in spite of the woven of words that have become part of an intellectual generation's argot. Though the author(s) don't go this far, and probably don't

\footnotetext{
demic English) of such "doing". As a consequence, many initiatives remain to go unnoticed by a larger (academic) public.

${ }^{15}$ It must be noted that most members of the department became geographers in a more positivist "milieu", having a more quantitative background.
} 
intend to, I think this is the question the reader is led to face." (07.04.2008)

Overall, representations and discourse remain of a central concern in research, and thus Groningen's cultural geography does resonate with elements Barnett (1998) has named as characteristic of "new cultural geography". However, perhaps [Anglo-American] geography currently finds itself in a period of developing a "new" new cultural geography in which the representational is viewed much more critically. It is unlikely that Groningen will adopt these newer directions very readily ${ }^{16}$.

It transpired from the above, that research (and teaching) in Groningen has been affected by its national framework of reference. And my own research has been impacted by my employment at the University of Groningen, as well as the agendas of funding agencies, the views of journal editors and social developments occurring all around me (see also Purcell, 2007; Cloke et al., 2004; Kitchin and Fuller, 2003; Lairumbi et al., 2008 and Garvin 2001 for discussion of the impact of each of those aspects on doing research). In the following, I want to zoom in a little further, explore a few examples of my own research.

\section{From "accidental geographer" to "cultural geographer"?}

As indicated in the prelude above, I am somewhat of an "accidental geographer" myself. My "elevator speech" on my research focus highlights "belonging and identities". I also like to experiment with methods. In this section, I describe two examples of research projects of which I think as most formative in my "being" a geographer.

\subsection{Experiencing prisons}

In October 2000, I began to correspond with a prisoner on Death Row in Livingstone, Texas. Throughout our correspondence, I went to visit him a few times. The issues we discussed via mail and my emotional and intellectual responses to the materiality of the prison led to a research project funded by the Netherlands Organisation for Scientific Research (NWO). It was a challenging period in which I had to negotiate more conservative attitudes towards researching prisons and an interest in studying prisoners' experiences and identities in a more exploratory way (e.g. by letting the respondents "take over" interviews). I did not approach the study with an aim of providing policy recommendations. A significant challenge was giving the emotional side of conducting research in prisons. Being somewhat confined by a

\footnotetext{
${ }^{16}$ Having said this, at the time of writing, there was a job opening for a full professor in Cultural Geography in the department. It is conceivable that the extent to which newer directions will become more or less important will depend, at least in part, on the selection made of this professor.
}

more conservative geography in the Netherlands, in which the position of the researcher is deemed largely irrelevant, as well as the everyday demands of work and life (and a pregnancy in between), this aspect remained utterly underexplored. Most of my pondering over emotional aspects of prison research were confined to a "public" research diary which appeared frequently in the faculty's student magazine Girugten between 2002 and 2004. In 2006, I presented some of the more "emotional" research at the Annual Meeting of American Geographers in Chicago but the paper remained unpublished ${ }^{17}$. It was not until 2006, when David Sibley joined our department as a visiting scholar, that I had the luxury of time and suitable company and became engrossed in the data collected. Whilst I brought the data (interviews with prisoners and correctional officers) and visual knowledge of the prison (from the inside), David brought new angles and literatures. Whilst my focus had been on identities (and particularly masculinities), David brought his interest in the psycho-analytical and a wealth of knowledge of various (often older and currently ignored) readings. This was an opportunity which I assume is rare for most academics, to spend hours discussing one's respondents' words in detail and exploring links to both our personal, academic interests and "necessary" works (such as a Foucauldian approach to prison). In spite of a significant amount of data that still remains unexplored and unpublished (but see van Hoven and Sibley, 2008; Sibley and van Hoven, 2009), this work and way of working, of "doing" has had a considerable impact on my "being" a cultural geographer.

\subsection{Walking with bears}

Another example of the luxury of time (and freedom) in "doing" geography is a project that, in many ways, took me back to my roots in physical geography whilst opening up new opportunities to try out new ways of generating data and transmitting these to different audiences. The project was producing a documentary on "the making of" Great Bear Rainforest (see backgrounder). I saw this as an interesting case of how a place is made, how different values are (re-)negotiated in complicated, emotional and lengthy meetings (see, for example, Clapp, 2004). It illustrates how representations and classification assign meanings, reproduce them and, assisted by science and media, naturalise them.

\footnotetext{
${ }^{17}$ The special journal issue from this session focused more on the non-representational aspects of hope, something I had largely ignored at that time.
} 


\section{Backgrounder Great Bear Rainforest}

The Great Bear Rainforest is an area which comprises 6.5 million hectares (twice the size of Belgium). It is situated along the coast of British Columbia, Canada, stretching roughly from northern Vancouver Island up to the border of Alaska. Depending on time, scale and discussion partner, the Great Bear Rainforest has variously been known as Mid-Coast timber supply area, the North and Central Coast of British Columbia or one of 29 First Nation territorial designations (Prescott-Allen, 2005). It is one of the last and largest remaining, intact temperate rainforests in the world. In 1997, environmentalists and forest industry clashed in this area over destructive logging practices (CBC, 1998, see CBC Archive "the fight for spirit bear"). When environmentalists targeted the international market, the forest industry saw their sales figures dwindling and agreed to begin negotiations over the future management and protection of the area. Negotiations between these parties, the provincial and national government, First Nations and various other stakeholders took over ten years.

All of the above issues are at the heart of what cultural geography in Groningen does, both in terms of research and teaching. In terms of teaching, it offered gaining experience in crafting a story about a contested place using a combination of moving and still images, narrations by people "on the ground" as well as music to underscore our intended message. When converted into a text (for an English, peer-reviewed academic journal), many nuances and emotions get lost in translation. For example, in our documentary, we wanted to give precedence to the First Nations since it was our aim to portray the area as a place that had belonged to someone before the environmentalists claimed it. It was important then for the audience to first see our First Nations respondents before any of the others. When introducing the area in the documentary using images of forests, water, and animals, we only use a voice that describes the ecological significance of the area rather than showing the narrator. The narrator is not First nation but one of the "environmentalist" respondents. In writing, the description of the Great Bear Rainforest as ecologically important area (by the invisible respondent) and the account by First Nations of the area as their home (since 10000 years) would all look the same: Times New Roman, black on white, possibly indented. Facial expressions, body language, pauses, wandering of a respondent's eyes whilst $\mathrm{s} / \mathrm{he}$ is thinking all remain hidden. Another aspect of story-telling in this visual way is the power of the producer to not only select quotes (as in texts) but to emphasise meanings through the use of certain kinds of images, the speed in which they are shown and fol- low each other and the choice of music. Again, this evokes a much greater emotional response than a written text where the message is conveyed in writing only ${ }^{18}$.

Due to the limited means to distribute such a videographic result amongst an academic audience, we were restricted largely to conferences which allowed extra time for showing the documentary (therefore allowing more space than just a 15-min slot in a session), or addressing a different audience altogether. We therefore focused on secondary schools and developed a book with in-class exercises to accompany the documentary and provide opportunities for going into more depth through these exercises (van Hoven and Logtmeijer, 2009). Within the faculty, this project was first treated with skepticism. It did not set out to target major journals and did not have funding for anything but travel and equipment. Most of the work therefore occurred in the spare time of staff involved and with the help of volunteers (for example for editing and providing additional score). However, the published book attracted relatively more attention than an account in an academic journal would have: many schools ordered the book, teachers sent excited responses and viewers were moved by the subject.

I wish to add here, too, the value of this project as a "personal journey" of "becoming". As such, the experience of being in the field, sharing space with large predators (grizzlies, black bears, wolves, wolverines) in close proximity, to smell their presence and to walk in a landscape made by bears ${ }^{19}$ rather than humans provided a physical experience of a topic that is hard to transmit in writing or otherwise. It is an embodied way of "doing" geography and "being" a geographer that reading theory and discussing readings can never provide. This embodied experiences, linked with the various stories by people in the area have strongly influenced my self-identity as cultural geographer in a way quite different from the "becoming" described in the prison research above. Nevertheless, the documentary project incited an interest in, for example, actor-network theory and non-representational theory which was woven into a co-authored chapter (with Louise Meijering) for the forthcoming volume Companion to Social Geography. In this chapter, I had the opportunity to revisit my work as physical geographer and make space for "the elements" in the production of knowledge (e.g. by considering the purposive agency of trees).

\section{Some thoughts on possible directions in cultural geographies}

There is no doubt that much of the cultural geography done in Groningen can be classified as "new cultural geography" with its focus on "the patterns and markers of differentiation

\footnotetext{
${ }^{18}$ Even where illustrations are added in written texts, these do not appear simultaneously with the image and sound.

${ }^{19}$ Grizzlies dig up sedge grass leaving the terrain rough and bumpy, and making for a challenging walk (by humans) across it.
} 
between people [and places], the processes through which these are made, and the ways in which these processes, patterns and markers are represented and ordered" (Valentine, 2001:167). The question really is, where it will go from here. In light of the time passed since the previous version of this article (the discussion paper), developments since, and the comments by referees, there is a need to address more structural issues that determine, at least to some extent, these directions. Increasingly, Dutch geography (and universities in general) have been subject to the neoliberalisation of scholarship. Competition and rankings have become key terms in the everyday doings and being of geographers both with respect to teaching ${ }^{20}$ and research. The success of competition and publication strategies is assessed, every six years, by an international panel of experts. As Lawrence Berg (as referee for this article) rightly points out, in the case of cultural geography in the Netherlands, this results in an assessment from an Anglo-American perspective conducted by researchers whose conceptual baggage is dominated by English thinkers and their writings in key English journals. In addition, the Faculty of Spatial Sciences ${ }^{21}$ has employed several "top researchers" as new professors, as well as senior research staff in tenure track positions. As a result, the everyday interactions of geographers, their everyday frameworks of doing and being, have increasingly been impacted by the experiences and expectations of those international researchers. A third development, also mentioned by van Weesep (2006) is the designation of centres of excellence or key research themes. Decisions for these themes are made at university level, involve established networks of professors, and are guided by themes put forward by NWO, research assessment outcomes and societal issues.

At the time of writing, Cultural Geography in Groningen was neither assessed as "very good" nor "excellent" in the last research assessment (in 2007). It has not been allocated research staff as a result of key themes or centres of excellence. However, the group did gain a Professor of Cultural Geography, Prof. Frank Vanclay (formerly from the University of Tasmania, Australia) ${ }^{22}$. Future research therefore will experience the pressure to perform better by international standards, to publish more and "better", to become

\footnotetext{
${ }^{20}$ For example, elsewhere, I discussed the impact of developments which force higher education "into the entrepreneurial spirit of the market" (van Hoven et al., 2010) which highlights the notion that students invest in their education and expect this to be successful. In order to be successful, they need to receive a degree which is given on the basis of a number of passed assignments and examinations. Lambert and Parker (2006) note that this "banking concept of education" reduces teaching and learning "to the act of teachers depositing knowledge in or upon students for them to store and reproduce, leaving no opportunity for dialogue, critical exploration, reflexivity and praxis." (p. 471).

${ }^{21}$ This development is not, however, exclusive to the Netherlands.

${ }^{22}$ and will attract another Chair for Landscape Valuation in the near future.
}

less eclectic. Having said this, with the strong presence of quantitative methodology adopted by people doing geography in this location, it is likely that a "refusal to get carried away with new trends" (Musterd and de Pater, 2003:555) will persist and the "new" new [Anglo-American] cultural geography will not be easily incorporated. It is interesting then to consider what style of scholarship will be established and in what way will this be recognised by a wider audience.

First of all, the focus on empirical investigation in Groningen may provide interesting contributions to some of the theories generated elsewhere, for example on belonging, community, rurality and identity. Secondly, there are at least two interesting foci in teaching (and related to research interests by staff) that already link with some newer developments in the UK. I already mentioned the central position of experimental methods and different ways of discovering knowledge. In addition to having the potential for some interesting work, it also provides opportunities to re-think the role and relations of and between researcher, respondents and "the elements" in doing research (see also van Hoven and Meijering, 2011). A second focus in teaching is on landscape which combines physical geography and social geography. This interest in building bridges between physical and social geography, rather than confining them to different locations in the curriculum (or even faculty ${ }^{23}$ ), offers exciting opportunities for research on/across perceptions of nature/culture (and the "divide"). Interestingly, it is here that connections can be made with writings on actor-network theory and nonrepresentational theory, again leading to the examination of epistemological questions ${ }^{24}$. A third and final point I wish to highlight is the emphasis on "relevant" research. Largely due to the Mansholt Chair in Rural Geography, which is funded by the government, a significant amount of money to spend on research comes from this Chair. This implies that cultural geography in Groningen will be shaped significantly by the contribution from this chair which is in the rural, the policy-oriented and the quantitative. There lies an interesting challenge here for cultural geography to bridge the gap between the applied and the abstract, and the quantitative and qualitative. Again the department is drawing on its researchteaching link to explore directions here by developing a new course on "applied cultural geography" which will attempt to combine, for example, issues raised in Oakes and Price (2008) with current social developments at the local scale, thus drawing out the possible policy-relevance of theory as well as their relevance to the everyday lives of ordinary people. In so doing, the department will keep working on establishing the kind of cultural geography they think matters ${ }^{25}$.

\footnotetext{
${ }^{23}$ Physical geography at Groningen is located within the department of cultural geography.

24 The course "heritage" could also be an interesting starting point (see, for example, Navaro-Yashin, 2009).

25 This "conclusion" is inspired by Noel Castree's introduction to the Forum "Research assessment and production of geographical knowledge" in Progress of Human Geography 30, 6.
} 
Acknowledgement. I would like to thank Tialda Haartsen, Peter Groote and Paulus Huigen for their ideas that contributed to this article. I found the comments of the three referees, Ben de Pater, Jörg Becker, and especially Lawrence Berg very helpful. I also wish to thank the special issue editors and Meredith Tavener for their spelling and reference checks.

Edited by: C. Felgentreff

\section{References}

Barnett, C.: The cultural turn: fashion or progress in human geography?, Antipode, 30, 4, 379-395, 1998.

Blunt, A., Gruffud, P., May, J., Ogborn, M., and Pinder, D. (Eds.): Cultural geography in practice, Hodder Arnold, London, 2004.

Bosco, F. J.: Actor-Network Theory, networks and relational approaches in Human Geography, in: Approaches to Human Geography, edited by: Aitken, S. and Valentine, G., Sage, London, 136-146, 2006.

Bosman, J. and de Pater, B.: Over centrum en periferie in de sociaal-geografische wetenschappen, met bijzondere aandacht voor de positie van de Vlaamse en Nederlandse geografen, in: Van Christaller tot Wallerstein, edited by: van Nuffel, N., Liber Americum Prof. dr. Pieter Saey, Nautilus Academic Books, Zelzate, 391-411, 2007.

Castree, N.: Research assessment and the production of geographical knowledge, Introduction, Progr. Hum. Geogr., 30, 747-749, 2006.

CBC: The fight over 'spirit bear'. May 27th, 1997, Clearcutting and Logging: the war in the woods, CBC Digital Archive, http://archives.cbc.ca/environment/environmental_ protection/topics/679-3924/ (last access: 1 March 2011), 1998.

Clapp, R. A.: Wilderness ethics and political ecology: remapping the Great Bear Rainforest, Polit. Geogr., 23, 839-862, 2004.

Cloke, P., Cook, I., Crang, P., Goodwin, M., Painter, J., and Philo, C.: Practising human geography, Sage, London, 2004.

Cosgrove, D. and Jackson, P.: New directions in cultural geography, Area, 19, 95-101, 1987.

Crang, M.: Cultural geography, Routledge, London, 1998.

Cresswell, T.: Place: a short introduction, Blackwell, Malden, MA, 2004.

de Pater, B.: Geography and Geographers in the Netherlands since the 1870s: Serving colonialism, education and the welfare state, in: Geography: Discipline, profession and subject since 1870, edited by: Dunbar, G. S., Kluwer Academic Publisher, Dordrecht, 153-189, 2001.

Dickhoff, J. and Groote, P.: De exotische mens in Teylers Museum, Geografie, 18, 4, 30-33, 2009.

Droogleever Fortuijn, J.: Gender representation and participation in Dutch human geography departments, J. Geogr. Higher Educ., 28, 1, 133-141, 2004.

Garcia-Ramon, M. D.: Viewpoint. Globalization and international geography: the questions of languages and scholarly traditions, Prog. Hum. Geog., 27, 1, 1-5, 2003.

Garcia-Ramon, M. D., Simonsen, K., and Vaiou, D.: Guest Editorial: Does Anglophone hegemony permeate Gender, Place and Culture? Gender, Place and Culture, 13, 1, 1-5, 2006.
Garvin, T.: Analytical paradigms: the epistemological distances between scientists, policy makers, and the public, Risk Anal., 21, 3, 443-455, 2001.

Gorp, B., Hoff, M., and Renes, H.: Dutch windows. Cultural geographical essays on the Netherlands, Faculteit Ruimtelijke Wetenschappen, Utrecht, 2003.

Haartsen, T., Groote, P. D., and Huigen, P. P. P.: Measuring age differentials in representations of rurality in The Netherlands, J. Rural Stud., 19, 2, 245-252, 2003.

Helms, G., Lossau, J., and Oslender, U.: Einfach sprachlos but not simply speechless: language(s), thought and practice in the social sciences, Area, 37, 3, 242-250, 2005.

Holloway, L. and Hubbard, P.: People and place: the extraordinary geography of everyday life, Prentice Hall, Harlow, 2000.

Kitchin, R. and Fuller, D.: Observation. Making the 'black box' transparent: publishing and presenting geographic knowledge, Area, 35, 3, 313-315, 2003.

Klaassens, M., Groote, P., and Huigen. P.: Roadside memorials from a geographical perspective, Mortality, 14, 2, 187-201, 2009.

Klunder, R. and Haartsen, T.: Esonstad: van vestingstad tot vakantiepark. Van mythe tot thema, It Beaken, 69, 1/2, 39-61, 2007.

Knippenberg, H. and van Schendelen, M.: Alles heeft zijn plaats: 125 jaar geograpfie en planologie aan de Universiteit van Amsterdam 1877-2002, Het Spinhuis, Amsterdam, 2002.

Lairumbi, G. M., Molyneux, S., Snow, R. W., Marsh, K., Peshu, N., and English, M.: Promoting the social value of research in Kenya: examining the practical aspects of collaborative partnerships using an ethical framework, Soc. Sci. Med., 67, 734-747, 2008.

Lambert, C. and Parker, A.: Imagination, hope and the positive face of feminism: pro/feminist pedagogy in 'post' feminist times?, Stud. High. Educ., 31, 4, 469-482, 2006.

Meijering, L. and van Hoven, B.: Imagining difference- The experiences of 'transnational' Indian IT-professionals in Germany, Area, 35, 2, 174-182, 2003.

Meijering, L., van Hoven, B., and Huigen, P. P. P.: Constructing Ruralities. The case of the Hobbitstee, J. Rural Stud., 23, 3, 357366, 2007.

Mitchell, D.: There's no such thing as culture: towards a reconceptualization of the idea of culture in geography, T. I. Brit. Geog., 20, 102-116, 1995.

Mouissie, A. M., van Diggelen, R., Apol, M. E. F., and Heil, G. $\mathrm{W}$.: Creation and preservation of vegetation patterns by grazing, Ecol. Model., 218, 60-72, 2008.

Musterd, S. and de Pater, B.: Country reports. Eclectic and pragmatic: the colours of Dutch social and cultural geography, Soc. Cult. Geog., 4,4, 549-563, 2003.

Navaro-Yashin, Y.: Affective spaces, melancholic objects: ruination and the production of anthropological knowledge, J. Roy. Anthropol. Soc., 15, 1, 1-18, 2009.

Oakes, T. and Price, P.: The cultural geography reader, Routledge, London, 2008.

Peake, L.: The challenge of feminist geography, J. Geogr. Higher Educ., 13, 85-121, 1989.

Prescott-Allen, R.: Coast Information Team review report, http: //ilmbwww.gov.bc.ca/citbc/c-citreview-jan05.pdf (last access: 1 March 2011), 2005. 
Purcell, M.: 'Skilled, cheap and desperate': non-tenure-track faculty and the delusion of meritocracy, Antipode, 39, 121-143, 2007.

Salemink, K., Haartsen, T., and Strijker, D.: Keten: kratjesstapelen en hokjesdenken?, Rooilijn, 42, 3, 206-211, 2009.

Sanders, E.: Doe maar gewoon, dan doe je al gek genoeg, in: NRC Handelsblad, Wednesday, 1 October 2008.

Short, J., Boniche, A., Kim, Y., and Li Li, P.: Cultural globalization, global English, and geography journals, Prof. Geog., 53, 1-11, 2001.

Shurmer-Smith, P. (Ed.): Doing cultural geography, Sage Publications, London, 2002.

Sibley, D. and van Hoven, B.: The contamination of personal spaceboundary construction in a prison environment, Area, 41, 2, 198206, 2009.

Trell, E. M. and van Hoven, B.: Making sense of place: exploring creative and (inter)active research methods with young people, Fennia, 188, 1, 91-104, 2010.

Valentine, G.: Whatever happened to the social? Reflections on the 'cultural turn' in British human geography, Nor. J. Geog., 55, 3, 166-172, 2001.

van der Vaart, R., de Pater, B., and Oost, K.: Geography in the Netherlands, Belgeo, 1, 135-142, 2004.

van Hoven, B.: "Can you write a memo on why we have to do gender, please?" An experiential account of teaching gender geography in the Netherlands, J. Geogr. Higher Educ., 33, 3, 315-325, 2009. van Hoven, B. and Elzinga, M.: "Bikes are such a nuisance" - Visually impaired people negotiating public space in Groningen, European Spatial Research and Policy, 16, 1, 131-144, 2009.

van Hoven, B. and Logtmeijer, A.: 'A forest for the future' in de klas, Groningen: Faculteit der Ruimtelijke Wetenschappen, Rijksuniversiteit Groningen, 2009.

van Hoven, B. and Meijering, L.: On the ground. Thinking through the production of knowledge, in: Companion to Social Geography, edited by: Cloke, P., del Casino, V., Panelli, R., and Thomas, M., Blackwell Publishers, forthcoming 2011.

van Hoven, B. and Poelman, A.: DIRECTIONS: Using computers for qualitative data analysis: an example using NUD.IST, J. Geogr. Higher Educ., 27, 1, 113-120, 2003.

van Hoven, B. and Sibley, D.: 'Just duck': the role of vision in the production of prison spaces, Env. Plan. D: Soc. Space., 26, 6, 1001-1017, 2008.

van Hoven, B., Been, W., Droogleever Fortuijn, J., and Mamadouh, V.: Teaching feminist geographies in the Netherlands: learning from student-led fieldtrips, Documents d'Anàlisi Geogràfica, 56, 2, 305-321, 2010.

van Weesep, J.: Research Assessment in the Netherlands, Progr. Hum. Geog., 30, 6, 751-753, 2006.

West, C. and Fenstermaker, S.: Doing Difference, Gend. Soc., 9, 1, 8-37, 1995.

Zijp, L. and Groote, P.: Moluks erfgoed in het Noorden, Noorderbreedte, 1, 29-31, 2009. 